\title{
GUN JUMPING IN BRAZILIAN ANTITRUST LAW: A CASE STUDY IN THE OIL INDUSTRY
}

Clarissa Brandão

Federal Fluminense University, Brazil.

Aline Teodoro de Moura

State University of Rio de Janeiro, Brazil.

Abstract: This article presents some of the main changes introduced in the Brazilian antitrust system with the publication of Law no. 12.529, 2011, which introduced important changes in the control of acts of economic concentration - mergers, acquisitions, formation of joint ventures - which now began to be performed by the competent authority prior to the act of concentration, avoiding the consummation of transactions without the consent of CADE and analyzes the concept of Gun Jumping. The legislative change imposes a challenge for the Brazilian antitrust system: to define the boundaries between a lawful process of economic concentration and a Gun Jumping practice. In particular, a study was conducted on these impacts on the national oil industry in order to evaluate the performance of CADE in the implementation of the legislation.

Keywords: Antitrust - Gun Jumping - Oil Industry.

\section{THE DEFENSE OF COMPETITION IN BRAZIL: BACKGROUND}

The country's competitive experience began in the 90s, with the 'Brasil New Plan', which introduced deregulation, trade liberalization, privatization of enterprises and economic stability.

Before this period, companies installed in Brazil were bundled under the protective mantle of the government, free from competition and not concerned with the quality and prices of the products offered. Therefore, the liberalization of the market became an important factor in the industrial and economic development of the country, while domestic companies began to seek better prices and quality in their production. 
In this new dynamic scenario, investments ceased to be merely speculative and began to be directed to production, therefore generating better income distribution, employment opportunities and wages, contributing to the country's development.

The concept of competition, borrowed from the economic sciences, provides the Law with the necessary parameters for the fulfillment of the constitutional guarantees listed in Articles 170 to 192 of the Constitution, in particular free enterprise and free competition. Free enterprise is enshrined in art. 170, sole paragraph, where we have:

It is ensured to all the right to engage in any economic activity, regardless of authorization from government agencies, except in cases provided by law.

Free enterprise involves the freedom of business and the freedom to hire. This means that the exploration of any economic activity is free, as long as the constitutional limits imposed upon it are respected, as the protection of competition is also in the Federal Constitution, in its Article 173:

$\S 4$ th. The law will repress the abuse of economic power aiming at the domination of markets, the elimination of competition and the arbitrary increase of profits.

\$5th. The law, without prejudice to the individual responsibility of the directors of the legal entity, shall establish the responsibility of the latter, subjecting it to the punishments compatible with its nature, in the acts performed against the economic and financial order and against the popular economy.

Competition, therefore, can refer to the market of factors as well as to the market of products. This is the "dispute for the acquisition of resources usable in production" (PINHO \& VASCONCELLOS. 2004, p. 15) and the "dispute for the purchase and sale of the final product" (PINHO \& VASCONCELLOS. 2004, p. 15). Therefore, the antitrust legislation seeks to ensure free and fair competition in the market, without having to limit free enterprise.

All business relationships are shrouded by the risk of trade. Carrying out a commercial activity implies taking on the risk of the business being or not successful. The defense of competition seeks to protect not the elimination of risks, but rather a fair dispute for the 
market and the opportunity for any agent to enter and remain in it, or leave it whenever he/she so desires, because he/she is driven by his/her own initiative.

Moreover, the commercial nature of competitive relationships is essential to enable the discussion of acts that violate the economic order. If there is no economic activity, no organization of productive factors for the obtainment of profit, there is no reason to speak of the right to competition. Competition Law governs the market and the relationships between its participants and consumers. The interests of the consumer and of the collectivity are also objects of Competition Law, which are, in the end, the legal assets protected by the Brazilian antitrust law, according to the lesson of Fábio Ulhôa Coelho,

\begin{abstract}
"by watching over the fundamental structures of the free market economic system, competition law ends up reflecting not only the interests of entrepreneurs victimized by practices harmful to the economic constitution, but also of consumers, workers and, through the generation of wealth and increased taxes, the interests of society in general." (COELHO, Fábio: 1995, p. 5).
\end{abstract}

Competition is not longer limited to the issue of price. Several other factors comprise it, such as, for example, technology, high productivity, investments in research. Its legal importance certainly derives from the fact of it being closely related to economic life and consumption relations.

There are two essential factors to understand the dynamics of competition: the characterization of its agents or subjects and identification of the product's relevant market.

We already know that the economic agents that integrate a competitive relationship will always be commercial entities, that is, companies and business people, companies or group of companies. There are, however, different markets, different activities and different clienteles. This is also the view of author Sérgio Bruna, since, according to him "not all goods compete against each other. Obviously, on the supply side, a producer of tractors does not compete with a drug manufacturer, which is why changes in the supply of tractors will have little or no influence in the amount of drugs produced " (BRUNA Sergio: 1997, p. 67). Complementing this reasoning, in his vote, the CADE rapporteur, Leônidas R. Xausa, defines that "competition establishes itself between equal business categories or between industries of the same sector or between dealers, but not between an industry and a dealer" (FRANCESCHINI: 1998, p. 291). 
So, to characterize a situation of competition we need the following elements: economic agents that contend for the same clientele through the production of a same or similar consumable good or through the provision of a same or similar service.

The concept of relevant market, for Sérgio Bruna, is the "economic space in which economic agents interact in order to determine the level of competition and the amount of economic power enjoyed by them" (BRUNA, Sérgio: 1997, p.76). This is also the position of CADE's jurisprudence, as can be seen in the following decision:

One may define the relevant market as the territory in which interested companies are involved in the supply and demand of products or services, in which the conditions of competition are sufficiently homogeneous and in which the conditions of competition are substantially different from those prevailing in neighboring territories (...) the product's relevant market is represented by the sum of products that can be reasonably substituted when used for the purposes for which they are produced, without failing to consider the quantity, purpose and, particularly, the price. (FRANCESCHINI: 1998, p. 531).

One may conclude that the concept of relevant market is quite technical because it is an economic concept used in the legal field to characterize situations of competition, or still to characterize the abuse of economic power.

For the analysis of antitrust issues, according to Sergio Bruna, "the characterization of economic power, for purposes of the repression of its abuse, will depend in advance on the definition of the relevant market in which it is manifested" (BRUNA, Sérgio: 1997, p. 43). This then means that the concept of relevant market, in addition to being extremely technical and complex, is instrumental to the extent that it is required to instruct the analysis of the occurrence or not of violations of the economic order, or abuse of economic power, according to the understanding of Sergio Bruna. Therefore, for him, "the concept of relevant market is instrumental in nature: it serves the purpose of identifying, subsequently, the existence of economic power" (BRUNA, Sérgio: 1977, p.89).

Also for Fábio Ulhôa Coelho, the characterization of the abuse of economic power only occurs after the relevant market of the business relationship in question is determined. According to him, "the notion of dominant position is relative and only has meaning with the 
specific geographical and material definition of the market in which this dominance is revealed" (COELHO: 1995, p. 58).

Therefore, it is understood that the relevant market is the geographical and material definition that limits the performance of the economic power of a particular agent. For example, we cannot assess whether or not a market suffered any damage as a result of the abuse of economic power, if this market is not technically defined, because, otherwise, the assessment of the extent of the result will not be reliable.

Therefore, it is not enough to just analyze that a particular economic agent has lowered its prices and in doing so incurred in a violation of the economic order ${ }^{1}$. It is necessary for the relevant market to have been affected. Otherwise, there is no basis to speak of the abuse of economic power, as nobody economically dominates the entire economy of a country no matter how much economic power he/she possesses.

Technically, the definition of relevant market is made in two aspects: geographical and material. The geographical aspect includes the geographical area of operation of the economic agent. And the material aspect is what determines the issues related to the consumer, that is, if he/she would have, in that market, substitutes for the product manufactured by the agent in question.

One of the best real examples found in this study to definitively understand what relevant market is, is the work of Sergio Bruna, where he mentions the Du Pont case, the cellophane company from the United States. This is a case decided by the U.S. Supreme Court, in which $\mathrm{Du}$ Pont claimed that it did not detain the dominant position in the cellophane market because cellophane did not constitute a market in itself but participated in the "flexible packaging materials" market, in which it accounted for only $20 \%$ of the total consumed materials; and therefore it had no "economic power" over the market, and could not be punished for abuse of economic power (BRUNA, Sérgio:1997, p. 77-79).

Sérgio Bruna also highlights in his work the understanding of the U.S. Supreme Court regarding relevant market: "That market is composed of products that have reasonable interchangeability for the purpose for which they are produced - price, use and qualities considered ${ }^{2}$." This understanding should also include the analysis of

1 Art. 36 of Law No. 12,529, 2011 provides: "Art. 36. Actions of whatever kind, regardless of blame, which have as their object or may have the following effects, even if they are not met, constitute violations of the economic order. I - to limit, restrain or in any way impair open competition or free enterprise; II - to control a relevant market of goods or services; III - to increase profits arbitrarily; and IV-abusively exercise a dominant position."

2 It is the rule of reasonable substitutability of one product by another considering their price, quality and use, according to Benjamin Shieber in Abuse of Economic Power, p. 43-49. 
the consumers' reaction. That is to say, it is not sufficient for the product to be technically interchangeable if the consumers reject it. It is called substitutability at consumers eyes.

Thus, Sérgio Bruna joins the current of American professor Hovencamp and also Arreda \& Kaplow, whose understandings as to the configuration or not of the abuse of economic power are similar. All agree that the application of one or other rule in analyzing the behavior of an economic agent is not sufficient to evaluate a possible economic offense is insufficient, but rather an extensive analysis involving the largest possible number of parameters. For instance, it is not enough to identify the relevant market, or the simple technique of replacing a product by another for such conduct to be characterized; rather the deepest and most complete analysis possible, gathering all available techniques.

Without a doubt, this is the best indication for the analysis of antitrust issues, but it implies the full understanding by the judges of the legal and economic doctrine that involves such issues, which does not occur so often in our legal system, leading many to commit errors, as for example, Preliminary Investigation 56/75, cited by Franceschini \& Franceschini, in Sérgio Bruna's book, which discussed the relevant market for configuring the abuse of economic power by a milk plant, in which CADE understood that there was no typical behavior by the plant in having cut the supply of milk to a distributor in Vila GalvãoSP because domain of the domestic market by the company was not characterized. However, one can immediately identify that the issue did not involve the domestic market but rather the relevant market of Vila Galvão, which was simply disregarded.

Another no less important element for competition is the identification of economic power. Its relevance is in knowing that, if there is no economic power by a specific economic agent, one cannot speak of abuse of economic power or infraction of the economic order. According to this same understanding, Sérgio Bruna states that

"The investigation into the existence of economic power, on a legally relevant level, is always indispensable since, in the absence of economic power, there is no possibility of performance of the State's antitrust activity, because if there is no power there will be no abuse to curb" (BRUNA, Sérgio: 1997, p. 125).

Economic power is the ability of an agent to have influence over the market in which it participates. For Sérgio Bruna, "the notion of economic power brings with it the antithesis of the model of perfect 
competition, where none of the economic agents is capable of influencing, with their individual attitudes, the behavior of the market as a whole" (BRUNA, Sérgio:1997, p. 103). Complementing, he continues stating that "economic power is the ability to determine third-party economic behaviors under conditions different from those that would result from the market system, if it functioned in a pure competitive system" (BRUNA, Sérgio: 1997, p. 105) and, further, "it may occur that the economic power enjoyed by a particular agent, although existing, does not possess the magnitude required to become the object of antitrust activity by the State" (BRUNA, Sérgio: 1997, p. 105).

The previous law - Law 8.884/94 - expressly took a position in art. 20, that, for the infraction to be characterized, the abuse of a dominant power is required. The new Antitrust Law followed the same orientation. The dominant power exercised due to a leadership position in the market is not an anti-competitive practice. Without dissonance, this is also the understanding of the doctrine, according to author Sergio Bruna, who explains that, in other words, market domination due to non-abusive conduct does not characterize illegal market domination. The concept of abuse of dominant position does not intrinsically offer better parameters for this situation to be clearly identified. In the words of Sérgio Bruna,

"one can say that the dominant position is one that confers its holder with a substantial amount of economic or market power, to the point that it can exercise decisive influence over the competition, especially with regards to the price formation process, either by attenuating the volume of supply or demand and that provides a high degree of independence in relation to the other economic agents in the relevant market" (BRUNA, Sérgio: 1997, p.115).

Sergio Bruna focuses the discussion on the issue of prices assuming it will not be possible to influence issues of competition without the agent having substantial control over prices. For him, abuse will only occur if it is shown that the agent practiced abusive prices, above or below the acceptable level, and produced real effects on the market through said practice. Without a doubt, pricing is important in the matter of competition, but it is not the only requirement for the practice of antitrust violations; we can provide an extreme example from the very work of Sergio Bruna, where he mentions, quoting Hovencamp, that to eliminate competition by exploding the competitors' factoryies, one only needs a saboteur and a match. 
Sergio Bruna understands that economic power can also be sized by elements other than market share. For him, the residual demand, price discrimination, the existence of excessive profits are also part of the antitrust analysis. He concludes in his teachings that all these elements are mere attempts to forecast the practice of anti-competitive actions in the marketplace, because according to Hovencamp, "predicting the competitive impact of a merger is not part of an exact science" (BRUNA, Sérgio: 1997, p.127)

It can be said that the definition of the situation of competition between different economic agents is complex, but essential for the characterization or not of economic offenses determined by the antitrust laws. Both the analysis of the relevant market, as well as the definition of the existence or not of economic power, are indispensable for the application of the antitrust laws that we will discuss in the next section.

\section{THE NEW BRAZILIAN ANTITRUST LAW}

The new antitrust law, Law no. 12.529/11 was published based on Bill 3.937/2004, resulting from an intense legislative debate that lasted seven years, justified by the major changes introduced to the Brazilian Competition Defense System (SBDC) - which is formed by the Administrative Council for Economic Defense (CADE) and the Secretariat for Economic Monitoring $(\mathrm{SAE})^{3}-$, to ensure the promotion of a competitive economy by means of the prevention and enforcement of actions that may limit or impair healthy competition for a relevant market.

Current legislation has brought innovation by organizationally restructuring the duties of the agencies involved in the Defense of Competition and assigning effectiveness and coercivity to CADE's decisions - which do not involve review by the Executive power ${ }^{4}$ - with the introduction of the system of prior control of acts of concentration, with the establishment of penalties for any breach of the Law.

From the organizational point of view, Law 12.529/2011, details the attributions and functioning of the entities responsible for

3 Art. 3 of Law 12.529/11 provides in article 3 that "The SBDC is formed by the Administrative Council for Economic Defense - CADE and the Secretariat for Economic Monitoring of the Ministry of Finance with the obligations provided for in this Law." Already when the SBDC is regulated by Law No. 8.884/94, it was composed by three bodies: the Administrative Council for Economic Defense (CADE), the Secretariat of Economic Law (SDE) of the Ministry of Justice and the Secretariat for Economic Monitoring (SEAE) of the Ministry of Finance.

4 Attention is drawn to the principle of guaranteed access to the jurisdiction under which states art. 5, XXXV, CF/88, "the law does not exclude from review by the Judiciary injury or threat of injury to the right." 
implementing the norms of Defense of Competition in Brazil, through the legal structuring of the so-called Brazilian Competition Defense System, a nomenclature which, even of general use, lacked legal provision until the enactment of the new law.

The main changes can be summarized based on the attributions of two bodies: a) CADE, which consists of (i) General Superintendence, responsible for the investigation and analysis of acts of concentration and anticompetitive practices; (ii) the Department of Economic Studies, responsible for the preparation of studies and reports; and (iii) the Administrative Court for Economic Defense, responsible for the judgment of cases, and b) the Secretariat for Economic Monitoring of the Ministry of Finance (SAE) ${ }^{5}$, which will be responsible for the advocacy of competition before government agencies and the general public .

We can point to the role of the SBDC in three basic areas: (i) the control of market structures, through the appraisal of acts of concentration; (ii) the repression of anticompetitive conduct; and (iii) the promotion of a culture of competition (FIGUEIREDO: 2013, p.234).

In this sense, an important change promoted by the new law was the change in the control of the market structures. Law no. 12.529/2011

5 SAE's duties are described in article 19 of Law no. 12.529/11.

6 Innovation of prior control brought by article 88: “Article 88. Acts of economic concentration that will be submitted to CADE by the parties involved in the transaction in which, cumulatively: I - at least one of the groups involved in the operation have been registered in the last balance sheet, gross annual revenue or total turnover in the country in the year preceding the operation, equivalent to or greater than $R \$ 400,000,000.00$ (four hundred million reais); and II - at least one other group involved in the operation has been registered in the last balance sheet, gross annual sales or total turnover in the country in the year prior to the operation, equivalent to or greater than $R \$ 30,000,000.00$ (thirty million reais). $\$ 1$ The values mentioned in items I and II of this article may be adequate, simultaneously or independently, by appointment of the Plenary of the Cade, by ministerial decree of the Ministers of Finance and Justice. $\S 2$ The control of mergers in the caput of this Article shall be made in advance and no more than 240 (two hundred and forty) days from the application protocol or its amendment. $\$ 3$ Those acts that are submitted to the provisions in this article may not be consummated before being analyzed under this article and the procedure laid down in Chapter II of Title VI of this Act, under penalty of nullity, being also imposed a pecuniary penalty of not less than $R \$ 60,000.00$ (sixty thousand reais) or more than $R \$ 60,000,000.00$ (sixty million reais), to be applied under the regulations, without prejudice to the prosecution of the administrative process, pursuant to art. 69 of this Law. $\$ 4$ Until the final decision on the transaction, the conditions of competition between the companies involved should be preserved, under penalty of the application of the sanctions provided in $\$ 3$ of this article. \& 5 The merger involving elimination of competition in a substantial part of the relevant market, which may create or strengthen a dominant position or which may result in the domination of the relevant market of goods or services, except as provided in $\S 6$ tof this article will be banned." We emphasize that the article was modified by Ministerial Decree no. 994, of May 30, 2012. 
is express in determining which merger, acquisition or joint venture operations should be necessarily considered in advance by the SBDC and analyzed a maximum of 240 days from the date of filing of the petition or its amendment, the consummation of which, without authorization by CADE, subjects those concerned to the imposition of a penalty and nullification; therefore, until the final decision on the transaction, the conditions of competition between the companies involved should be preserved.

Certain changes were also made to the illustrative list of behaviors that may constitute violations of the economic order, such as those listed in $\S 3$ of art. 36 of the Law, however, the list is simply, as stated, exemplary, as transcribed:

$\S 3$ The following acts, among others, to the extent that they constitute a hypothesis provided in the caput of this article and its items, characterize a violation of the economic order:

I - to agree, arrange, manipulate or adjust with a competitor in any form:

a) the prices of goods or services offered individually;

b) the production or commercialization of a restricted or limited amount of goods or the provision of a restricted or limited number, volume or frequency of services;

c) the division of parts or segments of an actual or potential market for goods or services by means, among others, of the distribution of customers, suppliers, regions or periods;

d) prices, conditions, privileges or abstaining in public bidding processes;

II - to promote, obtain or influence the adoption of uniform or concerted business practices among competitors;

III - to limit or prevent access of new companies to the market;

$I V$ - to create difficulties for the establishment, 
operation or development of a competitor or vendor, purchaser or financier of goods or services;

$V$ - to prevent access of competitors to sources of inputs, raw materials, equipment or technology, as well as distribution channels;

$V I$ - to require or grant exclusivity for the dissemination of advertising in mass media;

VII - to use misleading means to cause third party price oscillations;

VIII - to regulate markets for goods or services, establishing agreements to limit or control research and technological development, the production of goods or services, or to hinder investment in the production of goods or services or their distribution;

IX - to impose, in the trade in goods or services, upon distributors, retailers and representatives resale prices, discounts, payment terms, minimum or maximum amounts, profit margins, or any other sales conditions related to their transactions with third parties;

$X$ - to discriminate purchasers or suppliers of goods or services through differentiated pricing, or by establishing operational conditions for the sale or provision of services;

$X I$ - to refuse the sale of goods or the provision of services within normal business payment conditions;

XII - to hinder or disrupt the continuity or development of commercial relations for an indefinite period due to the refusal by the other party to abide by business terms and conditions that are unreasonable or anticompetitive;

XIII - to destroy, disable or take possession of raw materials, intermediate or finished products, as well as to destroy, disable or impair the operation of equipment to produce them, distribute them or 
transport them;

$X I V$-to take possession of or prevent the exploitation of the rights of industrial or intellectual property or technology;

$X V$ - to sell goods or services unreasonably below the cost price;

$X V I$ - to retain production or consumer goods, except to ensure coverage of production costs;

XVII - to partially or fully discontinue the activities of the company without proven cause;

XVIII - to subordinate the sale of a good to the purchase of another good or to the use a service, or subordinate the provision of a service to the use of another or to the acquisition of a good; and

$X I X$ - to exercise or abusively exploit industrial property rights, intellectual, technology or brand.

With regards to the penalties provided in the Law, one should point out the reduction of the parameters for the calculation of fines to be imposed on companies and their directors in the case of a conviction for the violation of the economic order, as provided in art. 37 of Law 12.529/12. Under the aegis of the previous law (Law no. 8.884/94), the penalty applicable to companies ranged from $1 \%$ to $30 \%$ of the economic group's gross revenue in Brazil, during its last financial year. The current Law establishes, for the company, a fine from $0.1 \%$ to $20 \%$ of the company's, group's or conglomerate's gross revenues obtained during the last financial year prior to the opening of the administrative process in the field of business activity in which the infraction occurred, whenever possible to estimate ${ }^{7}$.

7 Art. 37 provides: The practice of violation of the economic order subjects those responsible to the following penalties: I - for now, a fine of $0.1 \%$ (one tenth of one percent) to $20 \%$ (twenty percent) of the gross revenues of the company, group or conglomerate obtained, the last before the introduction of the administrative process in the field of business activity in which the infraction occurred, which will never be less than the benefit received, whenever possible in your estimation; II - in the case of other individuals or legal entities of public or private law, as well as any entities or associations of persons constituted in fact or in law, even temporarily, with or without legal personality, which do not carry out a business activity, it is not possible using the criterion of the value of gross revenue, the fine will be between $\mathrm{R} \$ 50,000.00$ (fifty 
For administrators, the fine to be imposed on companies and managers is now calculated based on the percentage incidence on revenues of the economic group in the field of business activity in which the violation occurred - and no longer on the revenue of the entire group - whenever possible to estimate.

\section{THE CHARACTERIZATION OF GUN JUMPING}

The theme of Gun Jumping is recent in the Brazilian legislative scenario; it is understood as the theory that lends itself to the analysis of alleged anticompetitive conduct practiced with the intent of controlling structures, arising mainly from the improper exchange of information and/or premature integration of companies in the process of economic concentration (MARTINS: 2012, p. 58).

In this sense, it is worth understanding the extent to which agreements, inherent in the process of economic concentration, may violate the rules of antitrust law, which is our proposal. The identification of the unlawfulness of Gun Jumping is related to the analysis of the competitive position of the parties, market conditions, the purpose of the operation and the nature of the due diligence and conduct prior to the consummation of the transaction.

As stated earlier, Gun Jumping is considered "jumping the gun." This expression can be easily understood if analyzed from the aspect of activities involving competition in which, whether sportive or economic, the starting conditions can define a good result. Therefore, transposing the idea to a process of economic concentration, a good start or a fast start can ensure the efficiency of the negotiation between the parties, as well as the planning and implementation of the operation.

However, it is noteworthy that the early implementation of the operation may cause a "false start" and therefore conflict with the rules of antitrust legislation, thus characterizing the practice of Gun Jumping. Law 12.529/11 completely changed the system used to control acts of economic concentration in Brazil. It innovated by introducing the preventative control of acts of concentration ${ }^{8}$. According to art. $88, \S \S 2$ and 3 of the Law, the control of the acts became prior to the

thousand reais) and $\mathrm{R} \$ 2,000,000,000.00$ (two billion reais); III - in the case of the administrator, directly or indirectly responsible for the infraction when negligence or willful misconduct is proven, a penalty of $1 \%$ (one percent) to $20 \%$ (twenty percent) of that applied to the company, as provided in subsection I of this article, or to companies or entities, as provided in section II of this article.

8 The subsequent analysis, as provided for the Law 8884/94 was largely ineffective and made the anticompetitive review extremely difficult for the proper agencies. With the change made by the new law, Brazil is aligned with countries that have the best antitrust laws. 
transactions and the transactions may not be consummated prior to their consideration by CADE, under penalty of sanctions to be imposed with the characterization of Gun Jumping:

Art. 88. Acts of economic concentration will be submitted to CADE by the parties involved in the transaction in which, cumulatively: [...] \& 2 The control of the acts of concentration addressed by the caput of this article shall be made in advance and, at most, within 240 (two hundred and forty) days from the protocol of the petition or its amendment. $\$ 3$ The acts that are subsumed to the provisions in the caput of this article may not be consummated before being analyzed, under the terms of this article and under the procedure laid down in Chapter II of Title VI of this Law, under penalty of nullity, being further imposed a pecuniary penalty of not less than $R \$ 60,000.00$ (sixty thousand reais) nor more than $R \$ 60,000,000.00$ (sixty million reais), to be applied in accordance to the regulations, without prejudice to the filing of administrative proceedings pursuant to art. 69 of this Law.

Regulation of this control can also be observed in art. 108, $\S 1$ of the Internal Rules of the Administrative Council for Economic Defense (RiCade) which establishes:

Art. 108. The application for approval of acts of economic concentration referred to in art. 88 of Law No. 12,529, 2011, will be made in advance. $\$ 1$ The notifications of acts of concentration must be filed, preferably after the signing of the formal instrument which binds the parties and before consummating any act relating to the transaction.

Previously, under the terms of Law 8.884/94, there was a subsequent control of structures, in which the companies submitted the legal matter to the analysis of the competitive authority only after its consummation.

Under the procedural aspect, Gun Jumping occurs when the parties of an act of concentration do not observe the requirement to notify the antitrust authority in advance or wait for the waiting period for analysis of the act.

As important as the procedural aspect is the observance of the 
material characterization of Gun Jumping: the improper exchange of information and/or premature integration between companies in the economic concentration process. We point out that when the competing parties coordinate their activities before the actual consummation of the transaction, there occurs a limitation of the functional independence of one of the parties - prior to the approval of the transaction by the antitrust authority -, which violates the prior control of the newly introduced Brazilian Competition Defense System, which excels in maintaining the conditions of competition in the market without restricting competition.

Therefore, the parties are not allowed to coordinate activities consisting in the exchange of commercially sensitive information that ensure to the defendant a competitive advantage in the market (as long as said information restricts or limits effectively or potentially the individuality of one of the companies that plan the integration) before closing the transaction - Jumping the Gun - and, if identified, will be characterized as anticompetitive conduct undertaken by companies in the process of economic concentration, since they must operate as independent competitors and thereby preserve their respective competitiveness until the final decision of the antitrust authority, CADE.

Nevertheless, the coordination of certain activities between the parties, even if understood as necessary, may be questioned by the antitrust authority. Note the need to establish minimum parameters for the occurrence of this prior coordination between the companies participating in a process of economic concentration (MARTINS: 2012, p. 73), thus avoiding the characterization of Gun Jumping; however, given the gap in the Brazilian legislation on the determination of these parameters, the analysis is performed on a case by case basis, as clarifies Leonor Cordovil,

"It is essential that CADE clarify to the companies which acts would have the capacity to consummate the legal transaction. In practical terms, it is expected that CADE clarify: (i) which steps the parties to an act of concentration may adopt before CADE's approval, (ii) what information can be shared between the parties during the course of due diligence and up until CADE's final decision; (iii) how and to what extent, if any, may the parties integrate assets and or the management of the companies (especially related to business management and marketing issues); and (iv) how to characterize and identify the unification of the exercise of power within companies before the approval of the act by CADE." (CORDOVIL: 2011, 


\title{
p. 213)
}

It is important to establish that in order to avoid the characterization of an illicit act of concentration and legitimize the conduct adopted by the parties, one must initially establish the moment of notification to CADE, before the beginning of its execution. It is worth noting that under Law 8.884/94, the parties signed contracts that included the suspension of the contractual effects depending on the CADE decision, being allowed to initiate the integration, as long as the irreversible business conditions were preserved.

As from the enactment of Law No. 12.529/11, the parties may not practice any action of integration representing the execution of the signed contract. According to the lesson of Gaban and Domingues,

\begin{abstract}
"Brazil, in the first moment of the application of the NLAB, will face a process (possibly painful) of maturing and of cultural change in which the risk of gun jumping is likely to be many times greater than the risk of the merit itself. For this reason, it is advisable that economic agents adopt, whenever possible, more conservative measures with respect to practices of the act of consummation in operations that have been notified to the SBDC" (GABAN \& DOMINGUES: 2012, p. 118)
\end{abstract}

\section{THE CASES IN THE OIL INDUSTRY.}

The changes in the new Brazilian antitrust law have an impact on several sectors of the economy, including the oil industry. In the upstream segment, certain operations and business transactions such as contracts for the sale of exploration rights (farm-in/farm-out) began to undergo a double analysis: by ANP and by CADE. The fines that may be imposed by CADE may reach 60 million reais in conjunction with the cancellation of the deal, in addition to inconveniently exposing businesses and the business of the sector.

Certainly antitrust analyses should and must be made relative to the oil exploration and production sector in Brazil, especially when considering the scenario of the pre-salt exploration and the fact that there was only one offer for the production sharing contract system. Even in relation to the post-salt and concession contracts, despite all the regulatory apparatus and the realization of public bidding processes aimed to elect the best concessionaires, the result of the bidding rounds is quite predictable, as shown in the table below: 
Graph I - Data of Bidding Rounds

\begin{tabular}{|c|c|c|c|c|c|c|c|c|c|c|c|}
\hline & $\begin{array}{c}\text { Bid } \\
\mathbf{1}\end{array}$ & $\begin{array}{c}\text { Bid } \\
\mathbf{2}\end{array}$ & $\begin{array}{c}\text { Bid } \\
\mathbf{3}\end{array}$ & $\begin{array}{c}\text { Bid } \\
\mathbf{4}\end{array}$ & $\begin{array}{c}\text { Bid } \\
\mathbf{5}\end{array}$ & $\begin{array}{c}\text { Bid } \\
\mathbf{6}\end{array}$ & $\begin{array}{c}\text { Bid } \\
\mathbf{7}\end{array}$ & $\begin{array}{c}\text { Bid } \\
\mathbf{8}\end{array}$ & $\begin{array}{c}\text { Bid } \\
\mathbf{9}\end{array}$ & $\begin{array}{c}\text { Bid } \\
\mathbf{1 0}\end{array}$ & $\begin{array}{c}\text { Bid } \\
\mathbf{1 1}\end{array}$ \\
\hline Blocks for bidding & 27 & 23 & 53 & 54 & 908 & 913 & 1134 & 284 & 271 & 130 & 289 \\
\hline Blocks transferred & 12 & 21 & 34 & 21 & 101 & 154 & 251 & 38 & 117 & 54 & 142 \\
\hline $\begin{array}{c}\text { Participation of } \\
\text { PETROBRAS }\end{array}$ & 5 & 8 & 15 & 8 & 88 & 107 & 96 & 21 & 27 & 27 & 34 \\
\hline
\end{tabular}

Source: Compiled from data obtained from the National Petroleum, Natural Gas and Biofuels Agency site

Obs.: BID - Auction

Since the opening of the sector in 1997, and, notwithstanding the flexibilization of the monopoly situation, today, in Brazil, the participation of PETROBRAS in the exploration of oil blocks in the onshore and offshore concession contract system is approximately $46 \%$, not taking into account the blocks referring to round zero and the rights obtained through farm-in farm-out operations in which the company participated.

Within this scenario, it should be emphasized that the new regulatory framework for the pre-salt, in addition to ensuring the participation of PETROBRAS as an operator in all blocks, did not regulate the manner in which the company will act as bidder. There is, therefore, a normative void that leaves in the hands of a highly asymmetric market the possibilities of association between PETROBRAS and other companies. As reported in the newspapers and trade journals, this "relationship" between the companies and PETROBRAS will not be governed by any bidding procedure that can guarantee the equality of conditions among all those interested in the pre-salt round. The economic power of PETROBRAS in the upstream sector is robust.

Within the scope of the concession agreements, the fines imposed by CADE on said operations significantly affect commercial negotiations of the national upstream segment. This is due to two reasons: a) change in the Brazilian competition system which now requires prior approval of acts of concentration, without any action having been carried out before this assessment (prior control); and b) the understanding by CADE and the ANP that the assignment of rights and obligations arising from the concession contract correspond to intangible assets of the companies and therefore are subject to the control of acts of concentration. 
Even though the new law has been in force since May 2012, it was from this year on that the National Petroleum, Natural Gas and Biofuels Agency - ANP declared mandatory the declaration of approval of the transaction by CADE to then analyze the concession process, through Circular Letter No. 003/2013/SEP.

According to the new Law and Ministerial Decree no. 994/2012, the concession transactions involving parties that cumulatively have an annual gross revenue (year prior to that of the operation) or total business volume in the country equivalent or superior to $\mathrm{R} \$ 750,000,000.00$ (seven hundred and fifty million reais) and the other party having an annual gross revenue (year prior to that of the operation) or total business volume in the country equivalent or superior to $\mathrm{R} \$ 75,000,000.00$ (seventy five million reais) must be submitted to CADE's analysis prior to its implementation

Each analysis of concession of rights implies in the opening of individualized administrative proceedings, whose costs correspond currently to a value of $\mathrm{R} \$ 45,000.00$ (forty-five thousand reais) to be collected via GRU (Federal Government payment docket), pursuant to art. 23 of Law 12.529/12.

Pursuant to art. 8, item III, the assignment of rights of concession contracts, especially when the operation is in the exploratory phase, tend to be analyzed via summary proceedings, with a duration of up to 240 (two hundred and forty) days unless CADE does not understand that it is a complex act. The current average time for consideration of acts of concentration by CADE has been 18 days.

The fine for non-submission to CADE of the acts of concentration vary between $\mathrm{R} \$ 60,000.00$ (sixty thousand reais) to $\mathrm{R} \$ 60,000,000.00$ (sixty million reais), in addition to cancellation of the transaction.

Regarding CADE, the following transactions involving the transfer of rights have been submitted and approved:

- BP / Devon (AC No. 08012.003431/2010-81 approved without restrictions on 5/19/2005);

- Mersk / SK (AC No. 08012.000097/2011-94 approved without restrictions on 3/2/2011);

- TNK / Petra (AC No. 08012.008374/2011-15 approved without restrictions on 9/14/2011);

- Petrobras / BG (AC No. 08012.008348/2011-89 approved without restrictions on 9/28/2011);

- TNT / HRT (AC No. 08012.010312/2011-65 
approved without restrictions on 3/14/2012); and

- Vale/Statoil, (AC $n^{o}$ 08700.000374/2013-72, approved without restrictions on 1/25/2013) ${ }^{9}$.

The strengthening of CADE with the new law and the changes in the competitive system came in good time. But there must be caution with a possible indiscriminate action over the economic agents involved, which merit a careful review on the functioning of the industry and its specific characteristics. In addition to, of course, a coordinated action between CADE and the ANP for the perfect handling of the matter in face of a notoriously troubled market.

\section{REFERENCES}

BRASIL. Lei n 12.529/11, de 30 de novembro de 2011. Planalto. Available at <http://www.planalto.gov.br/CCIVIL_03/_Ato2011-2014/2011/Lei/ L12529.htm >. Accessed on Feb. 19, 2014.

. Lei n 8.884/94, de 11 de junho de 2004. Planalto. Available at <http://www.planalto.gov.br/ccivil_03/Leis/L8884.htm>. Accessed on Feb. 19, 2014.

. Portaria Interministerial n. ${ }^{\circ} 994$, de 30 de maio de 2012. CADE.

Available at http://www.cade.gov.br/upload/Portaria\%20994.pdf. Accessed on Feb. 19, 2014.

BRUNA, Sérgio Varella. O poder Econômico e a conceituação do abuso em seu exercício. São Paulo: Editora RT, 1997.

COELHO, Fábio Ulhôa. Direito Antitruste Brasileiro: comentários à lei $n^{\circ}$ 8.884/94. São Paulo: Ed. Saraiva, 1995.

FIGUEIREDO, Leonardo Viseu. Lições de Direito Econômico. 6th ed. Rio de Janeiro: Forense, 2013.

FRANCESCHINI, José Inácio Gonzaga \& FRANCESCHINI, José Luiz Vicente de Azevedo. Poder Econômico: exercício e abuso - direito antitruste brasileiro. São Paulo: Ed. Revista dos Tribunais, 1985.

MARTINS, Amanda A. L. Gun Jumping, Controle Prévio de Estruturas e $o$ Cade. Revista do IBRAC, RIBRAC, 2012.

SILVA, José Afonso da. Curso de Direito Constitucional Positivo. São Paulo: Ed. Malheiros, 1998.

SHIEBER, Benjamin M. Abusos do Poder Econômico (Direito e Experiência Antitruste no Brasil e nos EUA.). São Paulo: Ed. Revista dos Tribunais, 1966.

FRANCESCHINNI, José Inácio Gonzaga. Lei da Concorrência conforme interpretada pelo CADE. São Paulo: Editora Singular, 1998.

9 Information available on the site www.cade.gov.br 
GABAN, Eduardo Molan e DOMINGUES, Juliana Oliveira. Direito Antitruste. SP: Saraiva, 2012.

TAUFICK, Roberto Domingos. Nova Lei Antitruste Brasileira. Rio de Janeiro: Forense, 2012.

CORDOVIL, Leonor et al. Nova Lei de Defesa da Concorrência Comentada. São Paulo: Editora RT, 2011. 